\title{
Geopolitical Changes in Caucasus After 1991
}

\author{
Stefan Georgescu ${ }^{a}{ }^{*}$, Tabriz Garayev ${ }^{\mathrm{b}}$ \\ ${ }^{a}$ Andrei Saguna University of Constanta, Romania \\ ${ }^{\mathrm{b}}$ Bucuresti University, Romania
}

\begin{abstract}
South Caucasus (also referred to as Transcaucasus), is a region situated to the south of the Greater Caucasus Mountain Range, composed of Georgia, Azerbaijan and Armenia. Due to the rich oil reserves of the Caspian Sea basin and geostrategic importance of the Caucasus as a crossroad between Europe and Asia, this region has always constituted a pole of attraction for the great powers of the world after the collapse of USSR. Not only neighboring countries like Russia, Iran, Turkey and Central Asian states (Kazakhstan and Turkmenistan), but also the United States, European Union and China are becoming actively involved in this region.

Thus, while Armenia has been allied with Russia and Iran, considering these two powers as a counterweight to Turkey - its main enemy in the region, Azerbaijan and Georgia have developed geostrategic alliance with Turkey, and the United States by promoting cooperation with NATO member countries. Moreover, the conflict in Nagorno-Karabakh had deprived Armenia of the possibility of cooperation with other South Caucasian states. Armenia, which bases itself mainly on the relationship with Russia, believes that maintaining good relations with Iran is vital in terms of its national security, therefore, Armenia encourages active presence of Iran in the region. Meanwhile, Azerbaijan and Georgia, which have developed geo-economic relations between them in course of time and expanded strategic partnership with Western democracies, particularly through the NATO alliance, put forth their best efforts in order to leave the sphere of influence of Russia.
\end{abstract}

Keywords: South Caucasus, energy project, energy corridor, Caspian Sea, strategic interests, economic interests, Caspian energy, oil, energy security

\section{Collapse of the Soviet Union}

After the collapse of the USSR the Caucasian region witnessed increased interest from the political and business community of the world. One of the main reasons for this is naturally the development of Caspian oil and gas recourses. The reach recourses of Caspian Sea which are found in Azerbaijani sector of the sea have attracted a horde of interested private and state-owned companies all over the world. ${ }^{1}$ The private Western interests in oil exploitation have been one important factor in raising the importance of the Caucasian region in the eyes of policy makers in the West. However important oil has been, it is nevertheless far from the only factor affecting the geo-strategic importance of the region. Ever since 1991, a struggle has been under way for economic and political influence in this southern part of former USSR; a struggle termed by some a renewed "Great Game". While now independent

\footnotetext{
* Corresponding author. Email: stefan102001@yahoo.com

${ }^{1}$ Suha Bolukba, "The Controversy over the Caspian Mineral Resources: Conflicting Perception, Clashing Interests", Europe-Asia Studies, Vol. 50, No. 3, 1998, pp. 397-414.
} 
Russian Federation has been attempting to reassert its influence over its former dominions, a new actors having interests in the region as Turkey and Iran immediately entered a race in which they at first could not accurately gauge their place. More faraway actors entered the race later for various reasons: the United States and the European Union, the latter only gradually and carefully mostly in the economic sphere. $^{2}$

Caucasian region saw a series of ethnic conflict right after the dissolution of USSR, however most of these conflicts have long history and some rose up even during the last years of existence of the USSR. Ethnic conflicts have plagued the Caucasus to a much higher degree than any area in Eurasia save former Yugoslavia. ${ }^{3}$ In the South Caucasus none of the conflicts that raged between 1988 and 1994 have found a lasting solution but are merely frozen along cease-fire lines. ${ }^{4}$ Being the land that separates Russia, Turkey and Iran from one another the region has a certain degree reverted to the situation in the eighteenth and nineteenth centuries, when it was the scene of the struggle between the Tsarist, Ottoman and Persian empires. ${ }^{5}$ However today the Caucasian states are themselves actors in international politics to an extent they have never been before. Whereas in the eighteenth century the rulers of Georgia for example constantly struggled for the continuance of their state, post-Soviet Georgia today enjoys a position in the international community which secures its continued existence. Furthermore it is pursuing a proactive rather reactive foreign policy - witness the emerging axes of co-operation such as GUAM. Nevertheless the Caucasian states remain weak compared to their neighbors. What is certain is that the role of the region in international politics is on the rise. The United States has for example defined Caucasus as a region of vital US interests. From where does the strategic importance of the Caucasus derive? I will try to outline how the Caucasus plays a significant role in the entire international politics of Eurasia. For this purpose, the relations between the three Caucasian states will be discussed then their role in intra-CIS politics will be outlined. Finally their position in the wider alignments of power in the Eurasian continent will be considered.

Among the three Caucasian states, the first striking observation to be made is naturally that two of the states - Armenia and Azerbaijan - are in a state of war, towards which the third state Georgia retains its neutrality. The war between the two republics which broke out in 1992 after four years of escalation led to the Armenian occupation of Nagorno-Karabakh and its surrounding regions totaling almost 20 per cent of the Azerbaijan's territory. In other words the war meant a clear victory for the Armenian side. But however having won the war Armenia has not managed to win the peace. Negotiations are deadlocked and Azerbaijan's standing in world politics is on the rise. There is a desire from Azerbaijan side to resolve the problem as fast as

\footnotetext{
2 James McDougall, “A New Stage in U.S.-Caspian Sea Basin Relations”, Central Asia (Lulea), No. 5, 1997

${ }^{3}$ Svante E. Cornell, Small Nations and Great Powers: A Study of Ethnopolitical Conflict in the Caucasus, Ricmond, Curzon Press, 1999

${ }^{4}$ Svante E. Cornell, “The Unruly Caucasus”, Current History, October 1997

5 John F. Baddeley, “The Russian Conquest of the Caucasus, London, Longmans, 1908
} 
possible by negotiations, but Armenian side blocks most of the initiatives. Armenian side believe that the time is in their favour - that the time passes and Azerbaijan will accept it lose in the war. And also that it will be harder for Azerbaijan to start a new war when there is a presence of international corporations in Azerbaijan in oil sector and a new war would be against their interests which logically would make them to put pressure on Azerbaijan to not begin a new war. To meet the eventuality of an Azerbaijani attempt at settling the conflict by force Armenia has forged strong military links with Russia. Azerbaijan on the other hand believes that "Armenia has bitten off more than it can chew"; that it "cannot sustain its position in the longer term" and that with increasing oil revenues, Azerbaijan can build a strong army, and either impose a political solution on Armenia or "obtain a military one". This seems to be proving true. Oil revenues increased Azerbaijani budget expenditures - particularly its military budget expenditures. In 2007 just Azerbaijani military budget was bigger than overall budget of Armenia.

The Armenian-Azerbaijani conflict has far-reaching consequences for the region and beyond. ${ }^{6}$ For the Caucasus its main implication is that it renders it impossible for the Caucasian states to act in concert against outside threats to the region. The fact that relations between the two warring countries follow the rules of a zero-sum game presents the possibility for extra-regional actors to get a foothold in the Caucasus by lending support to either party, thereby altering the balance of power in the region. This naturally translates into chronic political instability in the Caucasus. Moreover it helps to perpetuate the economic underdevelopment of the region. In practice the conflict has prevented the emergence in the region of stable and democratic political systems - a development that has also taken place in Georgia, for at least partly similar reasons. ${ }^{7}$ These conflicts have also made the Caucasian states prone to political violence and coup d'états, and have obstructed the process of democratization. This in turn serves the interests of the former hegemonic power Russia which to a great extent has supported centrifugal forces in the region with a view to weakening the existing states and making them more malleable to Russian influence. ${ }^{8}$ This policy has actually backfired on Russia itself. Indeed one can claim the existence of a link between Russia's actions in the Transcaucasus and the Chechen rebellion in the North Caucasus, insofar as the separatism Russia encouraged in the Transcaucasus spilled over to Chechnya. The linkages between events in the North and South Caucasus should not be underestimated. Also it could be said that this policy of Russia when it supports centrifugal forces in Georgia and Azerbaijan had actually worsen Russian position in Caucasus - because supporting a de facto unrecognized "smaller" side of the conflict

\footnotetext{
6 Stuart J. Kaufman, "Ethnic Fears and Ethnic War in Karabakh", Paper presented at the International Studies Association meeting, Minneapolis, March 1998

${ }^{7}$ Ghia Nodia, “Georgia's Identity Crisis", Journal of Democracy, Vol. 6, No. 1, 1995.

${ }^{8}$ Fiona Hill and Pamela Jewett, "Back in the USSR-Russia's Intervention in the Internal Afairs of the Former Soviet Republics and the Implications for United States Policy toward Russia", Harvard University: John F. Kennedy School of Government, January 1994.
} 
harms Russian relation with Georgia and Azerbaijan, which have no other opportunity than to appeal to USA in search of alliance.

Georgia's attempts to secede from the Soviet Union and ensuing refusal to participate in the CIS were countered by relatively overt Russian support for Abkhazian and South Ossetian rebellious minorities, who subsequently succeeded in achieving de facto independence. ${ }^{9}$ In the Armenian-Azerbaijani case, Russia seems to have followed a policy of weakening both parties by lending them both different degrees of support at different times. The advent to power of the nationalist president, Ebulfez Elcibey in Baku in the summer of 1992 led to a Russian policy very similar to the one in Georgia. Moscow increasingly supported the Armenian side in the conflict, but kept a low profile by supporting the Armenian state and not the Armenian insurgents in Nagorno-Karabakh directly, unlike in Abkhazia where a direct Russian hand was clearly more tangible. Hence, Armenia appeared as the main, sometimes even sole intervening party in the conflict. One can in other words conclude that even if forces in the Kremlin did not create the Caucasus's conflicts, though the general feeling in Georgia and Azerbaijan is that this was the case, strong forces were using ethnic divisions, and perhaps even doing their best to deepen them, to prevent the real independence of the Caucasian states.

As a result of these developments, a number of agreements tie Armenia to Russia very tightly, despite the fact that many Armenians are suspicious of Russia's intentions and that Armenia was one of the most intransigent republics to Soviet rule in the late 1980s. Armenia, in its present geopolitical situation, sees no other option but to ally with Russia for its security. Faced with the specter of the imminent de facto dissolution of the Georgian state in October-November 1993, Georgia was compelled to accept Russian troops on its soil and CIS membership to restore stability. Only Azerbaijan managed to avoid the return of Russian troops on its territory, but was forced to become a member of the CIS. As far as Georgian relations with the two belligerents are concerned, it is clear that Georgia's interests are in principle similar to those of Azerbaijan: the restoration of territorial integrity and of full independence from Moscow. Armenia, on the other hand, for the foreseeable future is dependent on a Russian presence in the Caucasus, and supports the countervailing principle of the selfdetermination of minorities, in particular for the Armenians of Nagorno-Karabakh. As a result, a considerable rapprochement between Georgia and Azerbaijan has taken place, based on a commonality of interests that will be discussed below. Simultaneously Georgia keeps amicable, although sometimes wary relations with Armenia. The Georgian leadership is aware of the potential danger of alienating Armenia. If nothing else, Tbilisi must constantly be aware of a compactly settled Armenian minority on its border with that country, factions of which have at times raised claims to political autonomy (in one event the Armenian government had to intervene to prevent the Armenians in Georgia from pushing the issue too far). Georgia's freedom of movement with regard to Armenia is hence limited.

\footnotetext{
9 Thomas Goltz, “Eurasia Letter: The Hidden Russian Hand”, Foreign Policy, No. 92, fall 1993;
} 


\section{The role of external powers in Caucasus}

\section{Position of Russia}

Russia is naturally trying to preserve its traditional geopolitical control over the Northern Caucasus and restore the influence it has lost in the countries of the Southern Caucasus. Its presence in the region is determined not only by the fact that the North Caucasian autonomous republics are part of the Russian Federation, but relies to a significant extent on the historical traditions and experience of the Soviet Union. An enormous role is also played by the interests of the Russian oil corporations which are actively involved in developing the region.

According to many independent experts, the crisis in the Northern Caucasus is caused to a significant extent by the negligent policy of the federal center. One of the main reasons for the Chechen conflict is the severe economic and social conditions in which most of the republic's population lives. The weakness of the local authorities, the strong clan and family associations which exist beyond the state laws and the vast amount of arms in the population's possession threaten to bring the region to complete anarchy.

Today, the Caucasian question is viewed through the prism of retaining the Russian Federation's integrity. The political forces in Russia are largely inclined toward resolving the problem by force, which is widely supported by the people.

\section{Position of the West}

Until recently, the West was essentially deprived, for several historical reasons (with the exception of several episodes between 1918-1920), of the opportunity to influence the Caucasian situation. But after the collapse of the Soviet Union the situation changed. The Euro-Atlantic Community, by enlarging its ranks with several former participants of the Warsaw Pact and upholding its interests in the Balkans, can apparently think about expanding its zone of influence. All the more so since the Caucasian and Central Asian states have already joined the Partnership for Peace program. The events in Chechnia have aroused much more attention in the West than the Karabakh conflict or the situation in Abkhazia at one time.

At the same time, the West is worried about the prospect of Islamic expansion in the Caucasus. And since Muslim mercenaries are fighting in many hot spots along the arch from Kashmir to the Balkans, many Islamic countries and international terrorist organizations are included in the concept of the Islamic threat. It seems the West does not want to aggravate its relations with Russia, but it is nevertheless inclined to build its influence in the Southern Caucasus, mainly in Georgia and Azerbaijan.

\section{Position of Turkey}


Russia's attempts to increase its influence in the Caucasus are arousing serious concern in Turkey. Ankara considers the Southern Caucasus one of its priority territories. In economic terms, it is interested in the transportation of Caspian energy resources, and in the political sphere, it would like to eliminate the potential conflict zone adjacent to unpredictable Kurdistan.

Turkey's foreign policy strategy is built on supporting independence and democracy in the Caucasian countries and involving the region in its sphere of influence. In this respect, it can rely on strategic assistance from the U.S., which is shown, for example, by the Turkish-American working group on the Southern Caucasus created to carry out bilateral working consultations.

\section{Position of Iran}

Iran can also claim the place of another significant geopolitical actor in the Caucasus, since it is located in the vicinity and has traditional historical and cultural ties to the region. At present, Iranian-Armenian relations are the most advanced. Teheran's activity is restrained by its relative international isolation initiated by the U.S. Nevertheless, Iran is interested in more dynamic participation in regional stability projects.

Some positive changes in Iran's domestic political life, the activation of its ties with the West, and the possible cancellation of American sanctions may create conditions for raising Teheran's role in regional politics. Iran's Caucasian policy (and its Caspian policy as a whole) is capable of providing the country with strong culturological and ideological arguments in its relations with the West, the U.S., and Turkey.

\section{Islamic factor}

Despite the action of the Russian authorities and optimistic statements by the military on imminent victory, the Islamic fundamentalists in the region today are an extremely serious force which is hatching grandiose plans to create an Islamic confederation of the Caucasian republics.

The militants enjoy the support of Islamic fundamentalists, in particular the Afghan Taliban. The governments of Islamic countries can do little to prevent their citizens from participating in armed conflicts abroad. In addition, such measures could lead to an open confrontation with the powerful Islamic organizations within these states. The rapid population growth and food shortages in Islamic countries must also be kept in mind, which are increasing migration pressure on adjoining regions.

\section{Ukraine's role in Caucasus}

The Ukrainian view on the events in the Caucasus differs from the European and Russian. Ukraine's attitude is formed primarily on the basis of its own national interests although it keeps in mind the possible reaction of Russian political circles.

The most acceptable alternative for Kiev in developing integration processes in the region is associated with the Black Sea-Caspian area. In particular, Ukraine is 
interested in the Caspian's energy resources and in building a Transcaucasian transportation corridor.

Ukraine is feeling the impact of the large-scale military action and conflicts in the Caucasus due to the inflow of refugees, which, in particular, is aggravating the general level of crime in the country.

Ukraine itself is encountering manifestations of separatism. Under certain circumstances, these trends could become dangerous and place the state's integrity in doubt. So the republic has an understanding attitude toward the similar problems in the Caucasus. Potentially, Ukraine may also have to use force to preserve its state sovereignty, implement measures to strengthen its border regime and raise spending on reinforcing internal security. Ukraine's active participation in the peacekeeping efforts in the Caucasus could be a much more acceptable way to prevent possible threats to security. Its neutral status allows Kiev to join the peacekeeping efforts under the auspices of international organizations without arousing a negative reaction among the states of the region.

Activation of Ukrainian policy in the Caucasus is promoted by general development of the situation in the CIS and, in the more global evaluation, of relations between the West and Moscow. In this respect, it would be best for Kiev to realize the potential of the GUAM states.

However, Ukraine's participation is not envisaged in the existing projects for achieving stability in the Caucasus, although it is not excluded. Apparently, much depends on the activity of Ukraine itself, and on its desire to become more actively involved in regional processes and uphold its interests, the urgency and importance of which are beyond doubt. On the other hand, certain circumstances force Kiev to reckon with Moscow's position, which has repeatedly expressed its negative attitude toward GUAM.

Nevertheless, the logic of the events is prompting Ukraine to take more active part in discussing the future outlines of the regional stability system. Otherwise, Kiev will lose its chance of building its influence in the region, and may be forced to give up once and for all one of the promising trends in its foreign policy.

\section{A Regional Security System for the Caucasus}

With the disintegration of the Soviet Union the Caucasus region became the site for some of the most serious inter- and intra-state conflicts. The political elites of the newly independent states have been well aware that their security could not be considered apart from each other, and that they were confronted with a pattern of ethnic conflicts which was specific for their region. Seen from this perspective, the Caucasus constitutes a regional formation with its own characteristics. This awareness of the regional dimension of the security problem did not lead, however, to the creation of a unitary institutional framework for the Caucasus favouring conflict settlement and regional cooperation. The failure in designing a regional security arrangement was not due to the lack of interest in the idea of Caucasian integration. 
Political movements in the region have developed a radical rhetoric of Caucasian unity, but with radically opposed contents. Caucasian unity has been defined in a way which may be considered as simultaneously over inclusive - the various views of Caucasian unity are generally based on a kinship relation, a cultural affinity or an alliance with nations or political forces which are external to the region - and under inclusive - the various views of unification generally exclude some of the nations and political forces from their definition of a unitary Caucasus. Non-regional states have been mapping the Caucasus in function of their own security interests. Their priorities are defined in military, political or economic terms. Such definitions lead invariably to the inclusion of the Caucasus into a larger regional framework, generally including the Caspian states and the Central Asian region. This risks to lead to a neglect of the specific regional pattern of conflicts and of the interdependency linking the various parts of the Northern and the Southern Caucasus.

These conflictual and dependency relations, which constitute a regional formation, are to be differentiated from the pattern of conflicts and interdependencies in adjacent regions. Definitions of the region in exclusively economic terms - such as the view of the Caucasus as part of a Silk Road linking European and Asian markets stress the common interests of all Caucasus countries but fail to address the complexity of a conflictual process of regional integration, in which economic interests are not always predominant.

The lack of regional institutional arrangements favouring associative forms of security led to attempts to address the security threats through balance of power policies. All regional actors have tried to revise the existing forms of distribution of power through alliances with regional and non-regional powers. Military policies figured high in such an approach to the regional security problems. The resulting system aimed at counterbalancing dominant forces but did not exclude hegemonic types of dominance.

Russia has been making use of its military preponderance in the region to build a close alliance with Armenia and to extract concessions from Georgia. It has secured a division of labour with the UN and the OSCE in their attempts to settle the secessionist conflicts of Abkhazia, South Ossetia and Nagorno-Karabakh. Georgian expectations of recovering its territorial integrity through cooperation with Russia have however not been met.

Russia failed likewise to find acquiescence in Azerbaijan for its regional policies and mediating activities. Russia's striving to establish a hegemonic role in the Southern Caucasus has further been weakened by its lack of economic resources and by political instability in the Northern Caucasus.

In their moves to counterbalance the Russian presence in the region, Western states are taking advantage of their preponderance in economic resources and military know-how. 
Countries such as Georgia and Azerbaijan are presenting their attempts to cooperate more closely with Western countries as a means of increasing their leverage in the internal and external conflicts in which they are involved. Linking their own security interests to the interests of Western states - though for instance common energy policies - would in their view secure a future increase in the provision of public goods such as military support or what further seems necessary to protect their territorial integrity. Such expectations are surely effective in creating legitimacy on the domestic level. Western support to Georgia and Azerbaijan has also strengthened their bargaining power vis-à-vis Russia. But it will be impossible, even with a significantly increased presence of Western powers in the region, to change the pattern of secessionist and ethnic conflicts in the region. The existing balance of power in the Caucasus is creating deadlock for all parties involved.

Non-regional powers striving for a hegemonic role in the region are unable to deliver sufficient public goods to secure security and economic development. The lack of integration, to a large extent a consequence of their own policies in the region, is hurting their long-term economic and military interests.

All the countries of the region have a positive attitude toward the idea of forming an all-encompassing system of regional security, and it is supported by other interested states. The problem is how and within what parameters to create this system. Various concerned sides are discussing different models, which boil down to two types.

First was elaborated at the Istanbul summit it proposes a group of participants according to the 3+3+2 formula (Georgia-Armenia-Azerbaijan + Russia-Turkey-Iran + the EU-U.S.A.) Leaders of the region are also in favour of broad participation by all interested sides. The idea of signing a Stability Pact for the Caucasus, based on the example of the Balkan Pact on the principles of the OSCE, was put forward at the OSCE summit in Istanbul by Azerbaijani President Heydar Aliyev. And later, during a visit to Georgia in January 2000, it was supported by former Turkish president Suleyman Demirel.

Another alternative is related to the Kislovodsk Process, the idea of which was developed by Vladimir Putin several years later. As early as June 1996, at the meeting of the presidents of three Caucasian states and the Russian Federation (the Caucasian Four) in Kislovodsk, Moscow proposed a program for the Caucasus based on the principles of respect for the sovereignty and territorial integrity of the Caucasian states and maintenance of peace and stability. This program also envisaged the geopolitical presence of Russia in the region. It proposed creating intermediary mechanisms for settling conflicts and strengthening cooperation with Turkey and Iran, but at the same time preventing external states (primarily the U.S.) from interfering in the Caucasus.

A project for forming a military-political alliance with the participation of Russia, Armenia, Iran and the possible inclusion of other countries was also highlighted in the Russian mass media. On the other hand, talks are being held on a Turkic consolidation of the region's states, an alliance between Turkey, Georgia, and 
Azerbaijan, etc. But all of this should be taken with a pinch of salt, since they are politically unrealistic projects. The creation of any military-political alliance in the Caucasus would lead to the appearance of new axes of confrontation, but would in no way promote the achievement of regional stability.

\section{The emergence of GUAM}

When evaluating the prospects for a particular project, the entire set of realities which have developed in the post-Soviet space must be taken into account. Geopolitical stratification on the territory of the former Soviet Union has led to the formation of two groups of states. One of them can provisionally be called the Northern Alliance and consists of the countries that signed the Collective Security Pact and are members of the Customs Union. The other can be called the Southern Group, which is the unofficial and still rather fragile association of GUAM states.

The interests of both groups of states are sufficiently interrelated, which is also confirmed by the functioning of the CIS mechanisms, the attempts to effectively reform the Commonwealth, and the demonstrative efforts of member-states to further develop bilateral relations. Moreover, internal forces of attraction within the framework of each of the groups are gradually beginning to prevail over those which bind them together within the CIS structure. The June 2000 CIS summit proved rather disappointing, particularly since no radical measures were adopted for forming a free trade zone. The anti-terrorist center, a decision about the creation of which was also made at this meeting, could become still one more inefficient CIS structure.

Keeping in mind their own interests, each of the designated formations is trying to endow the traditional geopolitical systems with more up-to-date content. A characteristic feature of the Northern Alliance is that it is centered around Moscow and consolidated around Russia, with which the interests of the political and economic elite of other member-states are tied. The northern group is demonstrating the will to consolidate and create supranational institutions of coordination and management. The Northern Alliance's greatest achievement is the formation of the Russia-Belarus Union, which on the whole also shows a general trend toward further consolidation of the group into a stronger structure. A large role is also played by the buildup in the power component in Russian political life, which is manifested in the stepping up of military activity in the Northern Caucasus, and an increase in the role of the Russian Security Council. A consolidating ideology is quite often built on confrontational thinking and the search for an external enemy, which in this case has been found in western imperialism or the Islamic threat.

The Southern Group is based primarily on common interests in economics and security. The common orientation of several of the group's countries toward the West due to the problems of socioeconomic development and the expectation that the West will help them to resolve their security problems is also a consolidating factor.

The countries involved in creating GUAM have approximately the same socioeconomic conditions, uphold similar foreign policy orientations, have common 
economic interests, and are developing common projects. Nevertheless, it is important to figure out how membership in GUAM meets the needs of each of these countries, how strong their attraction to each other is, and whether they can perhaps resolve the tasks of national development and security in a different way.

Within the framework of the CIS, the three Caucasian countries have sided with different alignments of states that have emerged in this organization. Armenia has been more closely drawn into a loose group of states that for different reasons work for the strengthening of the CIS, but share few other similarities or interests. Besides Russia, which is using the CIS as a tool to regain its lost influence over the former republics of the Soviet Union, this group includes Belarus, Kazakhstan and Kirghizstan. As mentioned, however, these states share few geopolitical interests except for the strengthening of the CIS as an institution, and can therefore hardly be called an emerging geopolitical bloc. Georgia and Azerbaijan, on the other hand, are involved as motors of a much tighter grouping of states that share significant common interests - the so-called GUAM. The acronym of the alignment is derived simply from the initial letters of the four countries - Georgia, Ukraine, Azerbaijan and Moldova. These four states all resist any further strengthening of the CIS at the expense of the sovereignty of member states. They see the CIS chiefly as an instrument of Russian influence over the republics, and want to broaden their international contacts westward and seek their security through western security mechanisms -mainly NATO. Another crucial characteristic these states share is the existence of a separatist autonomous minority on their soil, which they perceive Russia as supporting.

In the cases of Georgia, Azerbaijan and Moldova, the Abkhazian, South Ossetian, Karabakh Armenian, and Transdniestria separatist movements managed to achieve de facto independence and negotiations are equally deadlocked in all cases. In Ukraine, the secession of Crimea was temporarily averted relatively narrowly, but the situation is far from certain.

The relations between the four states intensified at a very rapid pace through late 90's. From simply having been an alliance of common interests in the framework of the CIS, the four have realized the potential of their co-operation, which has in turn led to a quiet institutionalization of their co-operation. Naturally, the four tried to keep a low profile in view of the hostile Russian attitude to their co-operation, and hence no institutions as such were created. Representatives of the four countries, however, met and coordinated policy regularly at CIS summits. An interesting development was that GUAM co-operation moved into the military field. The four countries announced in May 1998 plans to create a common peacekeeping battalion "under the UN aegis", in a clear attempt to avoid in the future the present reliance on Russian peacekeepers, especially in Georgia. In early December 1998, Georgian officials proposed that the four countries form such a peacekeeping force to "promote regional security and guard the proposed export oil pipeline for Azerbaijan's Caspian oil". The proposition also included a reference to its establishment within the framework of NATO's Partnership for Peace programme. In September 1998, the four countries also agreed to cooperate on border troops. Furthermore, and perhaps more importantly from a geo-strategic 
perspective, GUAM is attempting to act as a single entity in its relations with NATO in a so-called ' $19+4$ ' formula. Although such attempts are still little publicized, the group is actively promoting them. ${ }^{10}$ In the economic sphere, Ukraine and Moldova are interested in a role in the export of Caspian oil over the Black Sea to Europe, while Georgia and Azerbaijan, form a 'bridge' linking the Caucasian states to Europe in more than one sense. The four hope to play a significant role in plans to revive the 'Silk Road' from Europe to Asia - the TRACECA project, which will offer new and alternative supply routes to the existing Russian ones. The four countries have reached numerous bilateral agreements. As far as the Caucasus is concerned, Armenia is totally excluded from GUAM's co-operation schemes for the simple reason of Azerbaijan's presence in the group. In general, Azerbaijan and in particular Baku has become the political and economic hub of the entire Caspian region. With its oil resources and demographic strength, Azerbaijan is increasingly becoming the most powerful state in the Caucasus and hence has an increasing capacity to keep Armenia out of economic co-operation schemes, either with reference to GUAM or with the outside world. In the perspective of Azerbaijan's wish for a strong link to Turkey and the West, this makes the function of Georgia crucial to Azerbaijan: it is its link to the West, to Europe and to Turkey. This state of affairs has interesting implications for the Georgian-Armenian relationship. In pipeline politics, Azerbaijan excludes Armenia as a candidate to carry oil to the Turkish Mediterranean coast as long as the Nagorno-Karabakh conflict remains unsettled. And as Iran is impossible because of American objections, Georgia has, more or less by default, become the choice of the Baku-Ceyhan project. This project and the Baku-Supsa pipeline carry considerable importance for the strained Georgian economy. As a result, Tbilisi, from one perspective, has a vested interest in the isolation of Armenia, a more logical transportation route for many products, from Azerbaijan and Turkey.

What is more, taking into account the new trends in forming regional systems, GUAM could adjust its activity somewhat and pay priority attention to economic cooperation and security issues. This presumes Ukraine's inclusion in the regional stability system, on the one hand, and increase in the number of GUAM member-states and interaction with the OSCE, on the other. In addition, the strengthening of GUAM and the creation of regional mechanisms for the civilized resolution of conflicts could promote a reduction in ethnic tension, as well as ensure reliable operation of the transportation corridors in the south of the CIS.

But, unfortunately, the current level of interaction among the GUAM states clearly does not meet contemporary conditions and requires radical improvement. The prospects for developing this association depend on whether it can become, primarily, a full-blooded international organization with its own charter and clearly defined criteria for the participation, obligations and rights of its member-states, along with

\footnotetext{
10 Jared Feinberg, "GUAM: Creating Perceptions in the Caucasus", Summer Digest, Weekly Defense Monitor, Center for Defense Information, 1998
} 
corresponding collective coordination structures both at the supreme, and at the interdepartmental and interparliamentary levels.

The economic foundation of the new organization could be free trade zones within the framework of GUAM. In addition, a common information space must be created, as well as legal support of the free trade zones in harmony with the national legislation of all the states involved. Let us note that the GUAM countries do not participate in the Customs Union, but they support the idea of abolishing all restrictions on reciprocal trade.

An important avenue in GUAM's activity is forming joint mechanisms for ensuring stability in the region, including the safety of transportation and energy supply lines and cooperation with interested international organizations. This requires coordinating efforts in foreign policy, developing stable relations with the EU, the OSCE, the CIS Customs Union, and other international organizations. The expansion of GUAM is also possible, since it could be joined by Armenia, Turkmenistan, and Kazakhstan, as well as Poland, Hungary, and Slovakia.

At present, there are significant differences in the GUAM states in terms of level of economic development and rates of social reforms. To this should be added the incommensurate attitude of certain countries toward GUAM and other unfavorable factors. Nevertheless, with the goodwill of its member-states and the support of interested European countries and international organizations, we can hope for the efficient and competent implementation of the GUAM project.

\section{The Caucasus in Eurasian geopolitics}

Beyond the CIS, the Caucasus has become a primary ground for the proliferation of new regional alignments in the post-Cold War era. In a sense, what is happening on the Eurasian continent is, just like in the CIS, the subtle emergence of two opposing blocs, although that term is highly exaggerated at this point. It is necessary to point out that the web of relations that is emerging is in its early stages; there is no certainty of future developments. More importantly, though we speak of opposing alignments, it must be said that even among states falling on opposite sides, there may be shared interests and even interdependence in certain questions, which tends to blur the picture. As concerns relations between the states that span from the former Soviet Union south into the Middle East, it at present seems as if a division is developing between two groups of states. The first is basically a pro-Western group, proactive in foreign policy matters and anti-Russian in the framework of the CIS. This group generally resists Iranian influence and seeks to minimize it, and the US supports it on a large scale. On the other side, there is a set of countries which resent the increasing influence of the US and Turkey in the region and are in a conflict position with America's allies.

These states mainly follow a reactive foreign policy aimed at preventing through a variety of means-subversion in the case of Syria towards Turkey and perhaps Russia towards Georgia-the influence of Western-oriented states. 
Two crucial actors or pivots in this respect are Turkey and Iran. Turkey is a heavily Western orientated country with strong military ties to the US but an ambiguous relationship with the EU, which is very hesitant in accepting Turkey's role in their often narrow conception of Europe. Turkey is sometimes seen as the prolonged arm of the US in Central Asia and the Caucasus, especially by states in the opposing group. Turkey's main ally in the region has been and remains Azerbaijan. Turkey is the only country to have openly supported Azerbaijan in its conflict with Armenia and Turkey's economic and political influence in the country is tangible. ${ }^{11}$ Georgia has found it logical and necessary to improve its relations with Turkey despite the remnants of mistrust for Turks among Georgians in general, conditioned of course by a history not devoid of conflict. However, today Georgia's interests and orientations coincide in many respects with those of Turkey. The last few years have also seen the gradual improvement of Turkey's relations with Ukraine and Moldova. Turkey's interests in these countries are partly related to the Turkic minorities (the Gagauz in Moldova and the Crimean Tatars in Ukraine) but contain a heavy strategic component. Without wanting to alienate Russia with which Turkey has very important trade relations (another proof of the web of interdependence of today's international relations), Ankara has become a tacit supporter of GUAM - it is simply in line with Turkey's own interests to strengthen the independence of and cooperation among these states. Naturally, a possible point of contention is that Turkey and Ukraine are rivals for the transportation of Caspian oil. If oil quantities are really not as high as some observers hope, the oil will not be enough to satisfy every interested transporting country. The Baku-Tbilisi-Ceyhan pipeline project which was preferred to other routes underlines the importance of Turkey in transportation of Azerbaijani oil recourses to the Western countries. Georgia also benefits from this project as it was chose the link country between Azerbaijan and Turkey. There are some speculations that in the future other two Caspian states in Central Asia - Kazakhstan and Turkmenistan may join this project and their oil and gas recourses may be transferred to the West by this route. However it is necessary first to connect them to Baku-Tbilisi-Ceyhan route which itself is not certain because of economic and ecologic concern - mainly the ecologic risk of construction of a pipeline under Caspian Sea. On the other hand Central Asian countries have other alternatives for transporting their recourses - primarily through Russia - which is concerned in this question as it does not want oil routes to pass out of it is territory and is very hostile in this question. Another alternative may be even China - this is in the case if Central Asian countries "prefer the East to the West". China is not so far and its developing economy is hungry for oil resources. Even India is an alternative if a pipeline is build through Afghanistan and Pakistan. This case once more shows the importance of Caucasian and Central Asia not only as a holder of rich oil recourses, but also it extremely important geographical position - this region is surrounded by Russia, Turkey, Iran, China, India and Pakistan - all predicted regional and world powers of the twenty first century. Most of the surrounding powers,

\footnotetext{
${ }^{11}$ Svante E. Cornell, “Turkey and the Conflict in Nagorno-Karabakh: a Delicate Balance”, Middle Eastern Studies, Vol. 34, No. 1, January 1998
} 
furthermore, tend to be less than favourably disposed to Western, particularly American, influence in the region.

But let's return to our Caucasian region - besides oil interests, Turkey has important economic interests in the area, which holds new markets for Turkish industrial products of all sorts. No visitor to the Caucasus, even to Armenia with which Turkey has a closed border and no direct relations, can fail to notice the Turkish economic presence. Russia sees this Turkish penetration as very threatening, in particular as Turkish policy makers were somewhat euphoric about their country's possibilities of creating a "Turkic twenty-first century" back in 1991-92.

The second crucial actor is Iran. Iran has from the beginning been very realistic about its possibilities in the Caucasus. Seeing the impossibility of transposing the Iranian model to Central Asian countries, Iran was nevertheless worried about the adulation of the "Turkish model" in the region. Hence, Iran and Russia have found a common cause in seeking to prevent Turkish influence from gaining too much ground in the region. For Iran, which is mainly interested in stability - internal as well as external - on both sides of its northern border, accepting the return of Russian hegemony is preferable, if conducive to stability, to increasing Turkish influence. As a result of this, Russia and Iran have become increasingly aligned into what today forms a virtual strategic alliance. ${ }^{12}$ Both states share an aversion to US and Turkish influence in their neighborhood and work together to minimize it. In this context Armenia has become a logical part of the alliance, and in fact a virtual Moscow-Yerevan-Tehran axis has emerged, whose main function is to counteract Turkish influence.

As far as the Caucasus is concerned, Iranian policy has been very interesting and quite illogical on the surface to the outsider. Whereas Shiite clerics govern Iran, Azerbaijan is the only other sizeable country to have an overwhelmingly Shiite majority population. Despite this fact, Iran, after a period of neutrality, moved closer to Armenia and has become that country's main economic provider. Iran was from the beginning very worried about the creation of an Azerbaijani state to its immediate north as it feared this state could stir up irredentism among the perhaps thirty million Azeris in Iran, considerably more numerous than those in Azerbaijan itself. These fears in a sense became reality with the advent to power in Baku of President Elcibey in 1992, whose openly anti-Iranian rhetoric pushed Iran closer to Armenia. Today Iranian-Azerbaijani relations remain distrustful and occasionally hostile but on a working level. ${ }^{13}$

On the southern flank of these emerging alignments, it is difficult to overestimate the importance of the Turkish-Israeli strategic alliance. Especially for Arab states, some of which (especially Syria) feel directly threatened by the new

\footnotetext{
12 Galia Golan, Russia and Iran: A Strategic Partnership, London, Royal Institute of International Affairs, 1997 (Russia and Eurasia Programme, Discussion Paper No. 75)

${ }^{13}$ Svante E. Cornell, “Iran and the Caucasus”, Middle East Policy, Vol. 5, No. 4, January 1998
} 
partnership. The military pact between the two strongest military powers of the Middle East is an event that has redrawn the balance of power in the entire region. ${ }^{14}$

The same is true for Iran, which fears that it is also targeted by the alliance, notably given the existence of a close Iranian-Syrian relationship. In this context, Turkish and Israeli assurances that their relations are directed at no other state have not succeeded in calming Arab and Iranian fears. In a sense, closer relations between Iran, Armenia and Syria have reciprocated the Turkish-Israeli partnership. Interestingly, one can also see the participation of Greece, to a certain extent, in this latter grouping in a form of quadripartite consultative relations. With respect to the Caucasus, Israel has developed considerable interests in Azerbaijan, ${ }^{15}$ and is one of the largest sources of investment for the Georgian economy. On the other hand, the perceived target country of the Turkish-Israeli alliance, Syria, enjoys cordial relations with Armenia, beyond the familiar fact of its relationship with Iran.

\section{Links to the Middle East}

Another interesting development is how the Caucasus is increasingly being integrated into the security relations of the Middle East. Indeed, the alignments that characterize the Caucasian security complex can actually be drawn further down into the Middle East along the same criteria: one set of pro-Western, proactive states and one group of anti-Western, reactive states. The most notable inclusion to be made is Israel. Israel's role in the Caucasus and Central Asia is more important than most analysts normally acknowledge. In a recent study, Bulent Aras outlines the basic reasons that have brought certain Caucasian and Central Asian states closer to Israel. First, is the mutual fear of the expansion of Islamic fundamentalism and the desire to contain Iranian influence in the Muslim republics of the former Soviet Union. Second, is the fact of Israel's powerful image as a "model state: small but politically and economically strong, and both democratic and secular". Related to this, the concerned states see Israel's close relationship with the US and the West as a "gateway to the Western world in general, and to the United States in particular". Finally, Israel's economic assistance has been welcomed by these states, all of which desperately seek foreign investment. ${ }^{16}$ Indeed, Israel is among the three main states investing in the Georgian economy, for example. Among the states of the region, Uzbekistan and Azerbaijan are the ones to have attracted most Israeli interest. As regards Azerbaijan, Israel from the start took on an overtly pro-Azerbaijani stance in the NagornoKarabakh conflict. Some think Israel has supplied arms to Azerbaijan. Co-operation in the field of intelligence has also taken place; economically Azerbaijan is interested in Israel's technological expertise, while Israel hopes that Azerbaijani oil could reach Israel through an under-water pipeline from Ceyhan. Naturally, Iran has repeatedly

\footnotetext{
${ }_{14}$ Amikam Nachmani, “The Remarkable Turkish-Israeli Tie”, Middle East Quarterly, Vol. 5, No. 2, June 1998

${ }^{15}$ Bülent Aras, "Israel's Strategy in Azerbaijan and Central Asia”, Middle East Policy, Vol. 5, No.4, January 1998

${ }^{16}$ Bülent Aras, "Post-Cold War Realities: Israel's Strategy in Azerbaijan and Central Asia”, Middle East Policy, Vol. 5, No. 4, January 1998, pp. 69-70.
} 
warned Azerbaijan against pursuing and developing its ties to Israel, but such threats and warnings have not impeded the ties, rather the opposite. An interesting recent development has been that the Jewish lobby in the American congress has become increasingly supportive of Azerbaijan. Indeed, the Jewish lobby has come to a split with its one-time ally, the Armenian lobby, because of its support for Turkey and Azerbaijan. ${ }^{17}$

The Azerbaijani former Foreign Minister, Hasan Hasanov, was quoted as having stated, "We don't conceal that we rely on the Israeli lobby in the US". Importantly, the prospect of Azerbaijan playing an ever-increasing role in the IsraeliTurkish military relationship seems inevitable. As Azerbaijan feels increasingly threatened by Iran, Russia and Armenia, it finds little choice but to reciprocate by forming an alliance with Israel and Turkey in the military field, and will by extension benefit from the close links with the US that these states enjoy. Hence it seems likely that Israeli-Azerbaijani military co-operation will increase in the immediate future.

The Israeli connection has also been instrumental in bringing Syria closer to the Iranian-Russian alliance. Syria's security concerns have been aggravated by the Turkish-Israeli relationship and Syria is already aligned with Iran, and possesses good relations with Russian security structures since the time of the USSR. Moreover, ties with Armenia have kept growing since that country's independence, helped by the fact that several high Armenian officials-including former President Levon Ter-Petrosyan have close personal links with Syria. It is also not unlikely that the Greek government of South Cyprus will pursue closer links with Syria and Russia. The planned stationing of Russian S-300 missiles on the island was not an isolated event but a part of a larger pattern of increased Russian presence in Greek Cyprus. In addition, it should be noted that the once excellent relations between Greek Cyprus and Israel have plummeted to such a degree since Israel's alliance with Turkey that the Israeli president cut short a state visit to the island and returned home. In sum, the strategic alignments that are observable in the Caucasus have to a considerable degree been stitched together with the alignments existing in the Middle East. In a sense, this is a part of the inevitable reintegration of the region with its historical contacts to its south.

\section{The Caucasus: a Strategic Cross Road}

The main route for pumping oil from Azerbaijan to Europe is to pass through Georgia. Regardless of where the oil will travel on to, the Baku-Supsa pipeline is one of the most important links in the transit line. Georgia's significance has also grown in light of the projects to restore the Great Silk Road. The Republic is not hiding its intentions to enter NATO and, on the whole, is upholding a pro-western stance. Tbilisi is interested in settling the Abkhazian problem and is ready to cooperate with every country on this question.

\footnotetext{
17 David B. Ottaway and Dan Morgan, “Jewish-Armenian Split Spreads on the Hill-Strategic Issues Put Onetime Lobbying Allies at Odds", The Washington Post, 9 February 1999.
} 
However the Karabakh conflict and Armenian-Azerbaijanian relations are the main threat to regional stability. Whereas the events in Abkhazia, Chechnia, Ossetia and other hot spots can be related to internal state problems, in Karabakh we are dealing with an interstate conflict which has arisen from an internal ethnic problem. During the fighting in Karabakh, approximately 20,000 people have been killed and more than one million Armenians and Azerbaijanians have been forced to leave their places of permanent residence; Armenian troops occupied more than 20 percent of Azerbaijani territory.

The conflict is not only a source of instability in the region, but is also preventing cooperation among the Caucasian countries and hindering their full-scale participation in international organizations. This, in turn, is causing great difficulties in developing the regional political and economic infrastructure and preventing the attraction of investments.

Armenia had suffered a lot as a result of conflict with Azerbaijan. It economy suffered from being in blockade and having open borders only with Iran and Georgia. Turkish direct investments are also much lower than it potentially could be. So we could consider that Armenia already lost more than it gained from war with Azerbaijan where Armenia continued its tradition of expanding its territory on the expense of its neighbors which it started from the beginning of the last century right after gaining its first independence. People of one country must understand that the happiness of its people is not measured by how much territory it posses, (there are many examples of a small but very prosper nations) but rather by many other factors which of them is having good relations with your neighbors. Armenia however has territorial demands for three of four of its neighbors - it claims territory from Georgia, Turkey and Azerbaijan.

The Russian Federation is considered Armenia's traditional partner in the region. At least 20,000 Russian servicemen are deployed in Armenia. Nevertheless, Moscow's policy in the region has ambiguous consequences for Erevan. On the one hand, it is forcing Georgia and Azerbaijan to look for partners outside the region in order to form alliances without Armenia, and on the other, Armenia must think about more flexible forms of foreign political cooperation in the region and beyond it.

Azerbaijan, Turkey and Georgia see the expansion of military cooperation between Russia and Armenia as leading to further militarization of the region. The presence of Russian troops in Armenia is considered a guarantee for ensuring its interests in the Karabakh problem. The pro-Russian inclinations of significant groups of the country's population are based on this, as well as the plans for Armenia joining the Russia-Belarus Union. But the Stability Pact for the Caucasus envisages the withdrawal of Russian troops from Armenia, which makes Erevan's regional position extremely vulnerable. The Armenians understand that achieving peace will open its borders with its closest neighbors, Turkey and Azerbaijan.

As for Azerbaijan, it relies on Turkish support in its regional policy, and Turkey also provides its strategic rear in relations with Russia. Baku believes that stability in 
the Caucasus cannot be ensured without ultimate settlement of the Karabakh and Abkhazian conflicts.

The U.S. is not interested in Armenia's regional isolation and continuing tension in relations between Azerbaijan and Turkey, on the one hand, and Armenia, on the other. The U.S.'s greater participation in settling the Karabakh problem is due to its fears aroused by the strengthening of Armenian-Iranian ties and intensification of Armenian-Russian military-political cooperation. The U.S. is not averse to assuming the mission of an influential intermediary in settling the conflict.

On the other hand, if Erevan joins the Russia-Belarus Union, this will essentially thwart the idea of forming a regional security system and expand Russia's opportunity to increase its economic influence in the region, which could significantly change the distribution of forces and stimulate principally different processes in the sphere of regional security.

This alternative is understood in Armenia, which is forced to take into account its own unsuccessful attempts to solve the Karabakh problem, as well as the strong pro-Russian moods in the country. But the opportunity to implement this alternative is complicated somewhat by the clear striving of the Armenian leadership to conduct a more independent foreign policy, including its willingness to cooperate with GUAM Looking at the Caucasus from a healthy distance; a glance at the map speaks clearly. The eastward expansion of the Turkish-American alliance's influence into Central Asia depends on the rather tiny wedge that Georgia and Azerbaijan form between Russia, Armenia and Iran. Armenia's geographical location is crucial in that forms a wedge in the otherwise unbroken 'Turkic' chain that theoretically stretches from Istanbul to Chinese Xinjiang.

In the case of Georgia political situation changed after the "rose revolution" in 2003 in Georgia when Saakashvili was elected the president. This may be said the first truly democratic election in the Caucasus region and remains unique example on the Caucasian scene until now. Saakashvili's presidential period saw increasing of the stability in Georgia and stronger attempts to unity countries brake away republics. Except Abkhazia and South Ossetia - Adjarian autonomous region in the western part of country was also de facto ruled independently during Shevardnadze's rule and was close in its relations with Russia. Saakashvili resolved this problem within a few month after his victory in the elections. Further pressure was given on Abkhazia and South Ossetia. Relations with Russia had worsted gradually during his term mainly for this reason and a seek of Georgia to become a NATO member state. The possibility of joining of Georgia and Ukraine to NATO was discussed at Bucharest summit of NATO in April 2008 but as objection of Russia of seeing these neighbor states as a member states and fear of NATO's European members to worsen its relations with Russia had postponed their join to NATO.

\section{The United States' policy}


Moving to the role of the United States, it has passed through several phases since 1991. Initially, Washington was not to keen on asserting its influence in the region, acknowledging it as Russia's sphere of influence. This policy stemmed from, first of all, a persisting respect for the Soviet Union's position as a superpower, but it also stemmed from a lack of knowledge and initiative as concerned the Caspian region, as well as a lack of realization of American interests there. In the main, Washington limited its policy to espousing the Turkish model for the Muslim states emerging from the Soviet Union, supporting Turkey's quest for influence there as well as the true independence of the newly independent states. The lack of a proactive American policy in the region could be illustrated no better than by the way in which the Armenian lobby in congress was able to hijack American policy and use its influence to shape American policy in the Nagorno-Karabakh conflict. However, by 1994-95, the American policy was in a stage of transition. The Azerbaijani oil resources were beginning to influence the White House to treat the two parties to the conflict in a more equal way; however respect for Russia was still a crucial factor. The ground-breaking event was the war in Chechnya, which proved to US policy makers the actual (conventional) military capabilities of Russia: that it could create substantial amounts of trouble, but not mount a serious offensive military challenge. In other words, much of US respect for Russia was lost. It is no coincidence that US policy in the Caspian became increasingly assertive from the second half of 1996, and the US has announced that it considers the Caucasus and the Caspian a region of "vital US interests". In institutional terms, a most important factor, which is heavily linked with Azerbaijani and Georgian perceptions of American power, is the importance accorded to NATO as an institution. It has already been mentioned that GUAM is actively seeking to forge relations with NATO. Many Georgians, for example, believe that within few years, Georgia will be a member of NATO - the Alliance is seen as the only body that can actively safeguard Georgia's independence. The pace at which NATO Secretarygeneral and other officials visit the Caucasus indeed suggests closer relations emerging between the Alliance and the states belonging to GUAM.

\section{Iran and the Caucasus}

Iran's policy in the region is largely guided by geo-political state interests and less by ideological goals, such as promotion of Islam. With the collapse of the Soviet Union, Iran grasped that a potentially conflict laden zone had replaced its once stable northern border and that influences from the new states could permeate the internal Iranian arena. From the inception of their independence, Tehran took a very sober attitude toward the establishment of the new Muslim republics, seeing in this development the dangers that emanate from the internal ethnic factor in addition to the opportunities for expanded influence: The first ground for concern from the point of view in Tehran is the lack of political stability in the newly independent republics. The unstable conditions in those republics could be serious causes of insecurity along the lengthy borders (over 2000 kilometers) Iran shares with those countries. Already foreign hands can be felt at work in those republics, especially in Azerbaijan and 
Turkmenistan republics, with the ultimate objective of brewing discord among the Iranian Azerbaijanians and Turkmen by instigating ethnic and nationalistic sentiments.

Iran is a multi-ethnic society in which approximately fifty percent of its citizens are of non-Persian origin. The largest minority group is the Azerbaijanis, which comprise close to a third of the population of Iran. Other major groups include the Kurds, Arabs, Baluch and Turkmen. Many of these groups are concentrated in Iran's frontier areas, and most have ties to co-ethnics in adjoining states, such as Azerbaijan, Turkmenistan, Pakistan, Iraq and Turkey.

Thus, Iran's ethnic groups are especially subject to influence by events taking place in these bordering states, and the ethnic question is not merely a domestic matter. One of Tehran's chief goals in the region has been to prevent destabilization in Iranian Azerbaijan and a rise in ethnic-based activity among the Azerbaijanis in Iran.

Iran's cautious attitude toward the Caucasus is quite justified. Following the independence of the Republic of Azerbaijan, a flurry of activity associated with the probing of ethnic and national identity occurred among Azerbaijanis in Iran. The establishment of the Republic of Azerbaijan challenged the national identity of coethnics beyond the borders of the new state and served as a stimulant for many Azerbaijanis in Iran to identify with the Azerbaijani ethnic group though not necessarily with the new state itself. In the early 1990s, a significant rise in expressions of Azerbaijani ethnic identity in Iran has been observed, as well as important political manifestations of that identity. This rising Azerbaijani identity has generated few calls for the Azerbaijani provinces to secede from Iran and join the new republic, but rather for increased cultural rights within Iran.

Its close relations with Armenia illustrate the non-ideological nature of Iran's policy toward the region. Despite its rhetoric of neutrality in the Karabakh conflict, in and of itself inconsistent with the official ideology of a state that portrays itself as the protector and champion of the Shi'i in the world, throughout most of the postindependence period, Iran cooperated with Armenia despite its struggle with Shi'i Azerbaijan for control of Karabakh, evidently preferring overall that the Republic of Azerbaijan remain involved in a conflict, making it less attractive to Iran's Azerbaijanis and unable to allocate resources to stir-up "South Azerbaijan." Tehran adopted antiArmenian rhetoric only at times when the results of the conflict directly threatened Iranian state interests. Yet, the non-ideological nature of Iran's policy toward the Karabakh conflict, for instance, has not strengthened the stability in the region. Rather, Iran's cooperation with Armenia and its tacit support in the conflict with Azerbaijan over Karabakh strengthened Yerevan's actual and perceived power and consequently may have lessened its sense of urgency to resolve the conflict. Moreover, Iran's perception of fear of the Republic of Azerbaijan serving as a model for rising ethnicbased identity of its own Azerbaijani community has led it to have an interest in prolonging the Karabakh conflict, albeit on a low level of intensity. Iran has come to share an interest with Russia in protracting the strife; thus this factor has contributed to the cementing of Russian-Iranian cooperation in the Caucasus, additionally 
complicating conflict resolution here. Russia is interested in sustaining the conflict since it provides a means of influence and manipulation to promote Moscow's strategic, economic and political interests in the Caucasus, an area which it still considers a zone of highest importance, especially in the military and economic spheres. Moreover, the perpetuation of the conflict provides a means to preserve Yerevan's dependence on Moscow and thus its acquiescence to the stationing of Russian troops in its territory. External involvement and manipulation has been a major factor that has aggravated the Karabakh conflict and contributed to its protraction and escalation. Moreover, the dispute over the rights of the Azerbaijani minority in Iran and Baku's often irredentist activities serve as a major factor of tension in the relations between the Republic of Azerbaijan and Iran which have led to an increase in Baku's sense of isolation and vulnerability. This tension has impeded cooperation between Iran and Azerbaijan and adversely affected wider regional cooperation, while contributing to Baku's drive to seek association with western security systems, advancing the projection of Iranian-American rivalry into the already troubled Caucasus region. Advancing of Western presence in the Caspian region has reinforced Iran's threat perception from these developments in an area that borders its territory, adding an element, which contributes to instability in the region.

Tehran's policy toward the Karabakh conflict is a good example of the diversity of opinions, which contrasts with its monolithic image, evident in the foreign policymaking process in Iran. The prevailing official Iranian foreign-policy establishment promoted tacit support for Armenia in the conflict and expanding cooperation with Yerevan, evidently as a counter to potential Azerbaijani irredentism.

Iran attaches high importance to its relations with Russia, who has become a major political ally and an important partner for both economic and military cooperation, thus was careful not to harm its relations with Moscow.

Overall, the official Iranian statements and media was quite mild in its criticism of Russia in these wars, despite the Muslim background of the Chechen rebels, and Iranian officials frequently commented that the conflict was an internal Russian matter. Official Iranian condemnation was only aired at times that other issues in the state-tostate relations between Iran and Russia were in conflict over other issues. Moreover, Iran's complaisance on the Chechen issue was often rewarded by Moscow by a reaffirmation of its commitment to supply Tehran with its strongly sought after nuclear reactors.

\section{Islam in the Caucasus}

Talking about Caucasus we could not pass not mentioning about religious composition of its nations. The use of religious labels regarding the various sides to the hostilities in the Caucasus contributes little to understanding the roots of these conflicts and subsequently, finding appropriate solutions. Islam is not the primary collective identity of most of the Muslims of the Caucasus, and plays only a minor role in the conflicts afflicting the region. Not all violence perpetrated by Muslims is Islamic terror, and not all political movements involving Muslims are Islamic movements. Most of the 
observant Muslims in the region are not connected to Wahabbism and this label is often inappropriate. The major coalitions of states involved in the conflicts are not based on religious affinity. In terms of external actors involved in Islamic radicalism in the region, most of them originate from countries with are considered pro-Western: Saudi Arabia, Pakistan and Turkey (primarily non-official groups). The activity of "Afghani Arabs" in the region is a source of instability and concern. Iran's policy in the region is based primarily on geopolitical concerns, and the propagation of Islamic fundamentalism is only a minor facet of their activity in the region.

Some may argue that the main reason of the conflicts in Caucasus are religion and the conflicts are fought between Muslim and Orthodox Christian countries. However if we look more carefully we could find inter Orthodox conflicts like in Georgian conflict, between central government in Tbilisi and unrecognized republics of Abkhazia and Southern Ossetia. Iran's policy toward the conflicts in the Caucasus is driven by its state geo-political interests, and little by Islamic ideology. Moreover, Iran engages in Islamic propagation in the Caucasus almost exclusively when it cannot damage its strategic interests in the area, and often uses Islam manipulatively in order to advance those interests, primary vis-à-vis Russia.

For most of the Muslims of the Caucasus, Islam serves as a component of their ethnic and regional identity, but is not their primary collective identity. Solidarity on an Islamic basis with Muslims beyond the Caucasus is minimal, although beginning to emerge among small groups in the North Caucasus. Most members of the region hold in high regard their local cultures, and they are not particularly susceptible to chief identification with the broader Muslim world. Furthermore, Islam rarely serves as a unifying ideology of primary identity uniting the Muslim residents in the region, and many conflicts prevail among members of the same religion.

Outside forces have too easily labeled mass forms of dissent in the region as "Islamic". For example, when Azerbaijanis removed border posts in December 1989 in attempt to make contacts with their co-ethics beyond the border in Iran, Western sources tended to interpret this as their desire for ties to "Khomeinism" in Iran. More recently, activity of Chechens involved in what they view as a national struggle for independence is predominately termed in the West as "Islamic" violence and activity, despite the fact that Islam plays a quite secondary role in the conflict. Islam in and of itself is not destabilizing and not all ethnic or regional conflicts in which Muslims are involved are inherently religious. Not all acts of violence and terror perpetrated by Muslims should be seen as Islamic terror. The Islamic label and the Muslim origin of many of the peoples of the Caucasus is often manipulated for promotion of their own agendas by a variety of forces, both within and from outside the region. With Western audiences and at home, Moscow forthwith throws the Islamic label on movements of Muslims within its border demanding political independence or autonomy in order to cast aspersion on them and to attain American sympathy and acceptance of its policies against the insurgents. In the Soviet period, pious Muslims were generally referred to by the misnomer "Wahabbists", which had a more frightening association then simply observant. Russia has continued with this labeling of Muslim activists, despite the fact 
that few of the Muslims in the Caucasus are actually connected to Wahabbist movements. Muslim radicals in the Middle East also like to attach the Islamic stamp to uprisings in the Caucasus and Central Asia and often grant support to political movements in this area, even if the basic goal of the movement is not Islamic in nature, although in the long run, they can gain influence in this manner.

As a conclusion we could say that the conflicts in the Caucasus have created interesting bedfellows, beyond the cooperation between Iran, Armenia and Russia, diverging from nominal lines of religious or "civilizational" affinity. For instance, Chechen activists assisted Moscow in aiding the Abkhaz in its struggle with Georgia. Furthermore, initially after the Soviet break-up, transports of food supplies to Armenia went through Turkish territory, often to the chagrin of Baku.

The use of religious labels to categorize the various sides to the hostilities in the Caucasus contributes little to understanding the roots of these conflicts and subsequently, finding appropriate solutions. Western relative lack of a business-like approach to the grievances of the Muslim peoples of the Caucasus and their assumptions concerning their motivations in the struggles can act like a self-fulfilling prophesy and push many of the Muslim peoples of the Caucasus into radical Muslim arms.

\section{CONCLUSION}

Summing up the discussion above, the "pieces" fall into place relatively clearly. The web of relations emerging in the Caucasus, Central Asia and the Middle East after the demise of the bipolar world in 1989-91 seems now to begin to crystallize into a new set of alignments. However deep the trenches may seem to have been dug in certain cases, especially among the smaller players in these emerging alignments, there may presently not be a need to evoke the example of the danger of alliance systems that provoked the First World War, although there are, in principle, certain similarities. It is a fact that economic interdependence is the rule of the day, and that the major actors in this "Great Game" to a certain degree keep working relations, except for the case of Iran and the US. Turkey's commercial links with Russia are crucially important to both countries and thereby exercise a degree of control over the foreign policies of both states -Turkish economic interests in Russia actually account for several times its economic interests in Central Asia and the Caucasus as a whole. Likewise, Turkey has always kept working relations with Iran, despite the rivalry between the two states. In a sense it does make sense to speak of the two as rivals but not as enemies. The same goes for Russia and the US despite the recent deterioration of relations due to the recognition of Kosovo's independence by US. Furthermore, Armenia's special relationship with the US is another factor that breaks through the general picture of relations described above.

It is arguably too early to dwell on the potential threats posed by the emergence of these conflicting or competing alliances. However, the main danger for international security is that either of the larger states would be drawn into a military confrontation between two minor powers on opposing sides of the alignments. The Armenian- 
Azerbaijani conflict offered such dangers in 1992-94, which were nevertheless avoided because of Iranian and Turkish caution about upsetting Russia, which in fact threatened a third world war in the event of Turkish interference. The event of renewed fighting between the two countries does indeed constitute a considerable danger to international security, which no other conflict in the region does to the same extent. A significant difference would be the level of armaments of the parties. Armenia has, for example, acquired weapons worth over a billion dollars from Russia, and Azerbaijan may in the future use its oil resources to buy similar amounts of weaponry. Given the geographic size of the area of conflict, the repercussions on neighboring countries will definitely be greater this time around, a fact worth further analysis. The regional alignments in Eurasia are an important dimension in the emerging international politics of Eurasia. As such, they need to be further discussed, analyzed and managed. The lack of this could make the deterioration of relations in case of regional crises, and ultimately the risk of escalation of hostilities, more salient than it already is today.

\section{ANNEXES}

1.Map of Azerbaijan khanates of in $2^{\text {nd }}$ half of $18^{\text {th }}$ century ${ }^{18}$

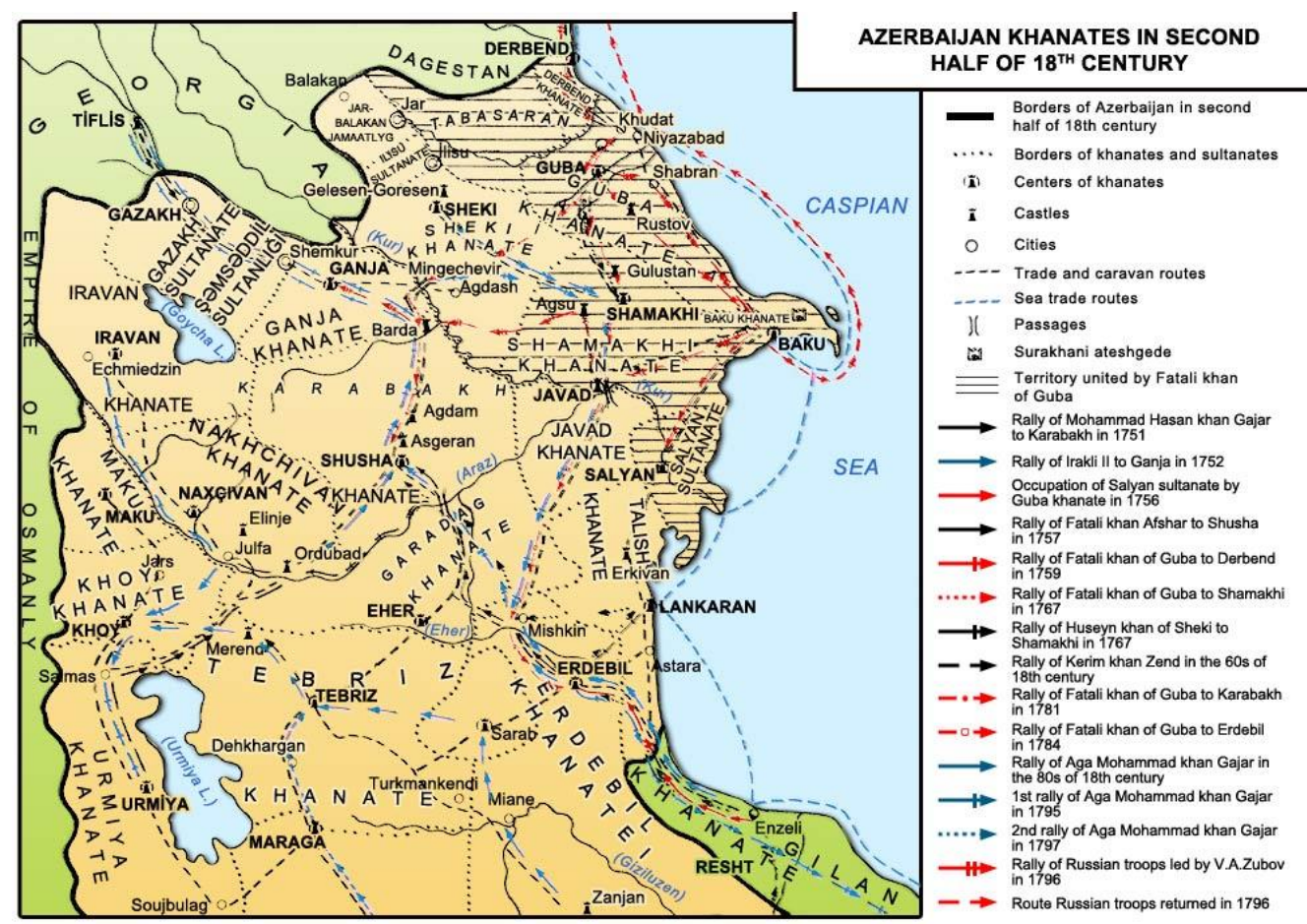

${ }^{18}$ http://www.azerbaijan.az/_History/_HistoricalMaps/_historicalMaps_e.html 


\section{Administrative map of the Caucasus during USSR ${ }^{19}$}

Administrative map of Caucasus in USSR, 1952-1991

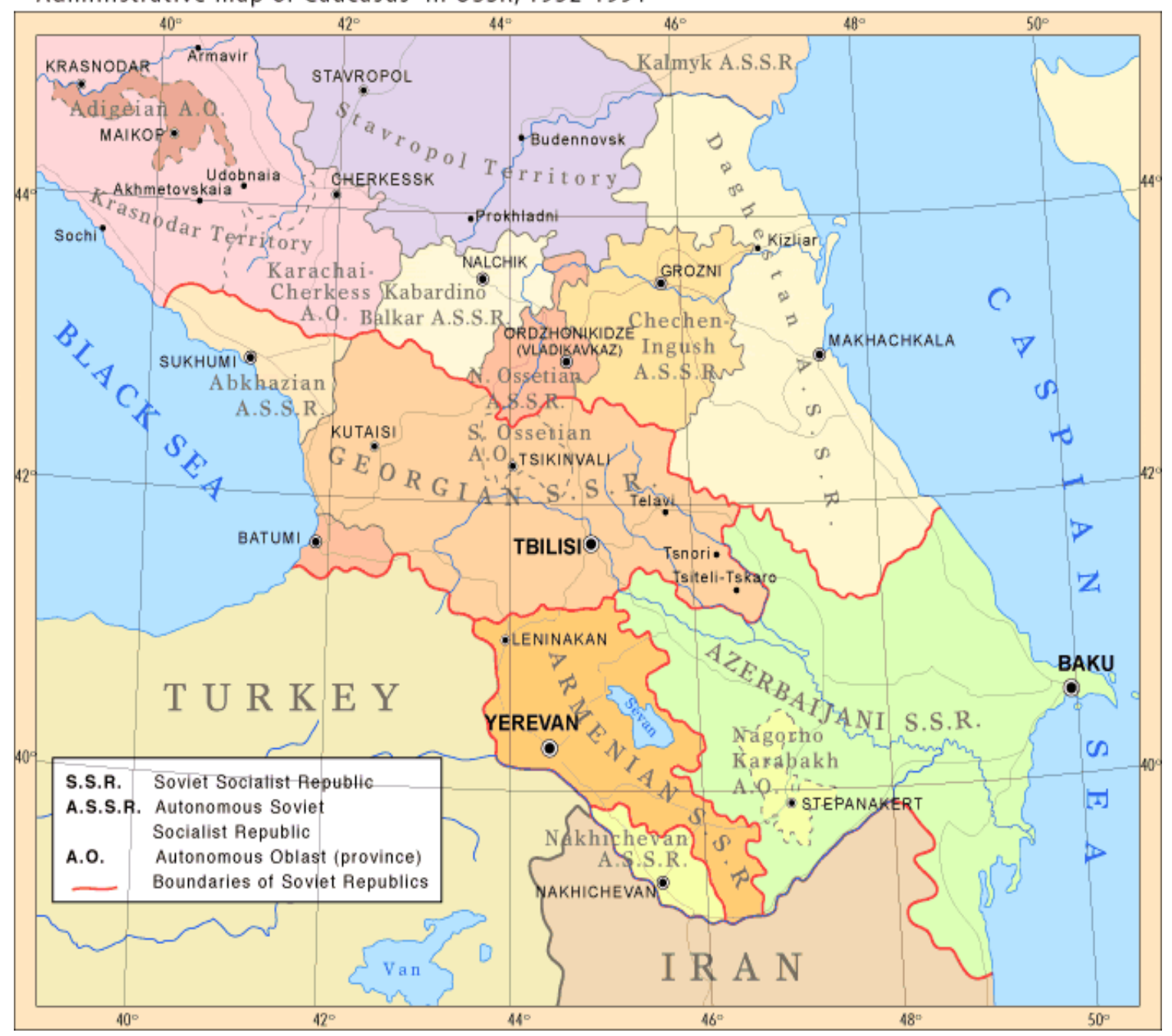

${ }^{19} \mathrm{http}: / /$ en.wikipedia.org/wiki/Caucasus 
3.Map showing peoples of Caucasus ${ }^{20}$

Ethnolinguistic Groups in the Caucasus Region

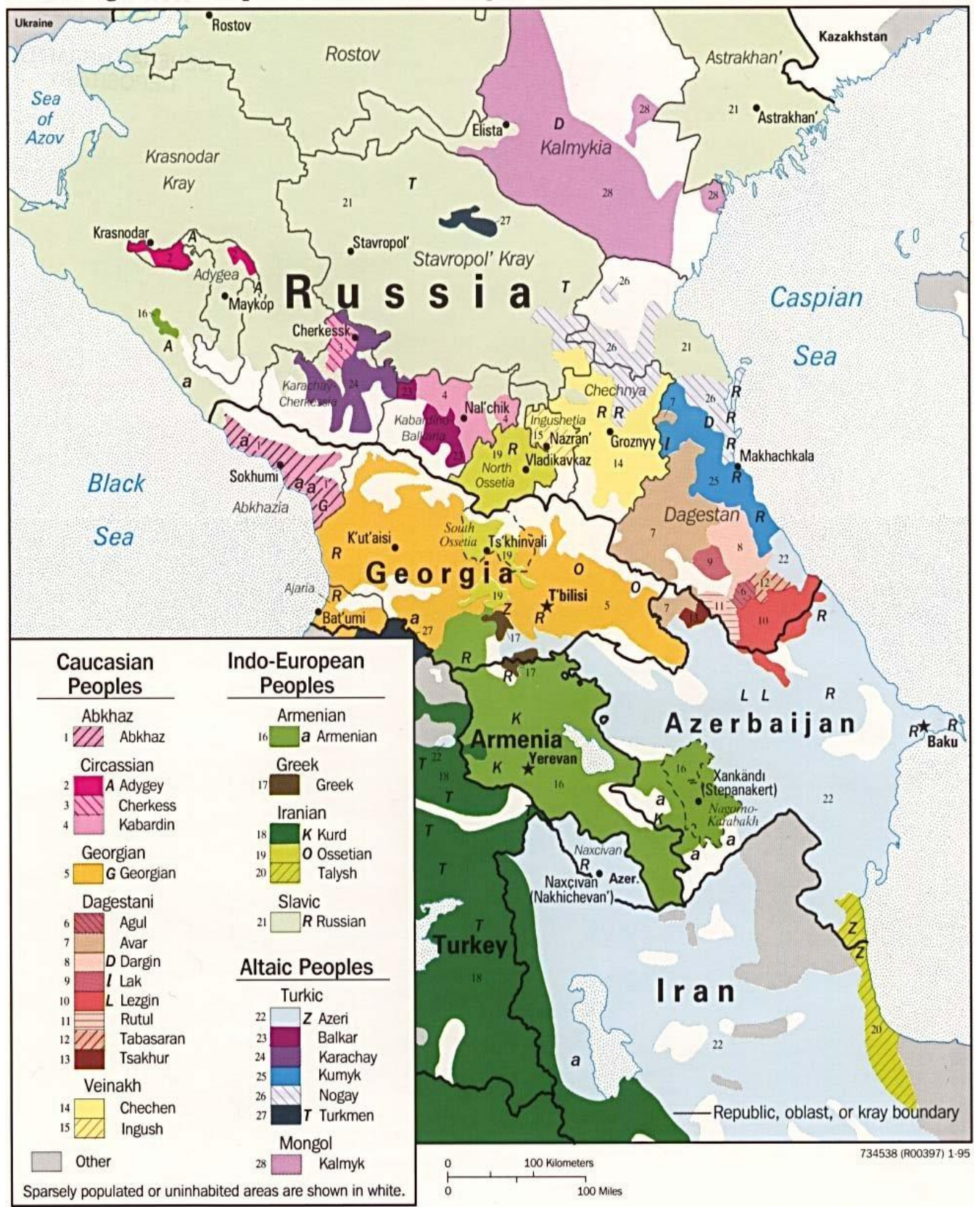

${ }^{20} \mathrm{http}$ ://en.wikipedia.org/wiki/Peoples_of_the_Caucasus 


\section{BIBLIOGRAPHY}

Allen, W.E.D., "A History of the Georgian People"

Amikam Nachmani, "The Remarkable Turkish-Israeli Tie"

Braund, D., "Georgia in antiquity: a history of Colchis and Transcaucasian Iberia 550 BC - AD $562 "$

Bulent Aras, "Israel's Strategy in Azerbaijan and Central Asia"

Bulent Aras, "Post-Cold War Realities: Israel's Strategy in Azerbaijan and Central Asia"

Cornell, Svante "Iran and the Caucasus"

Cornell, Svante, "Small Nations and Great Powers"

Cornell, Svante, "The Unruly Caucasus"

Cornell, Svante, "Turkey and the Conflict in Nagorno-Karabakh: a Delicate Balance"

David B. Ottaway and Dan Morgan, "Jewish-Armenian Split Spreads on the Hill-Strategic Issues Put Onetime Lobbying Allies at Odds"

Encyclopaedia Britannica Online: History of Azerbaijan

Encyclopedia Iranica - "Albania"

Erich Feigl, "Mitomania Armenilor"

Fiona Hill and Pamela Jewett, "Back in the USSR - Russia's Intervention in the Internal Afairs of the Former Soviet Republics and the Implications for United States Policy toward Russia"

Firouzeh Mostashari, "On the Religious Frontier: Tsarist Russia and Islam in the Caucasus"

Galia Golan, "Russia and Iran: A Strategic Partnership"

Ghia Nodia, "Georgia's Identity Crisis"

Igor Rotar, "Tbilisi Has Only Partial Control Over Georgia's Armenian Regions"

James McDougall, “A New Stage in U.S.-Caspian Sea Basin Relations"

James Stuart Olson, "An Ethnohistorical Dictionary of the Russian and Soviet Empires"

Jared Feinberg, "GUAM: Creating Perceptions in the Caucasus"

John F. Baddeley, “The Russian Conquest of the Caucasus”

Ira Lapidus, "A History of Islamic Societies"

Ronald Grigor Suny, “The Making of the Georgian Nation”

Stuart J. Kaufman, "Ethnic Fears and Ethnic War in Karabakh"

Suha Bolukba, “The Controversy over the Caspian Mineral Resources: Conflicting Perception, Clashing Interests" 
S. Georgescu, T. Garayev / Journal of Institute of Social Sciences 3 (2), 2013, 123-151

Tadeusz Swietochowski, "Russia and Azerbaijan: A Borderland in Transition”

Thomas Goltz, "Eurasia Letter: The Hidden Russian Hand”

http://www.britannica.com

http://www.cac-biodiversity.org

http://www.historymedren.about.com

http://www.livius.org

http://www.metmuseum.org

http://www.wikipedia.org

http://www3.nationalgeographic.com 